\title{
Gefitinib in Non Small Cell Lung Cancer
}

\author{
Raffaele Costanzo, ${ }^{1}$ Maria Carmela Piccirillo, ${ }^{2}$ Claudia Sandomenico, ${ }^{1}$ \\ Guido Carillio, ${ }^{3}$ Agnese Montanino, ${ }^{1}$ Gennaro Daniele, ${ }^{2}$ Pasqualina Giordano, ${ }^{2}$ \\ Jane Bryce, ${ }^{2}$ Gianfranco De Feo, ${ }^{4}$ Massimo Di Maio, ${ }^{2}$ Gaetano Rocco, ${ }^{5}$ \\ Nicola Normanno, ${ }^{6,7}$ Francesco Perrone, ${ }^{2}$ and Alessandro Morabito ${ }^{1}$
}

\author{
${ }^{1}$ Medical Oncology Unit, Thoraco-Pulmonary Department, National Cancer Institute, 80131 Napoli, Italy \\ ${ }^{2}$ Clinical Trials Unit, National Cancer Institute, 80131 Napoli, Italy \\ ${ }^{3}$ Medical Oncology Unit, Azienda Ospedaliera Pugliese-Ciaccio, 88100 Catanzaro, Italy \\ ${ }^{4}$ Direzione Scientifica, National Cancer Institute, 80131 Napoli, Italy \\ ${ }^{5}$ Thoracic Surgery, Thoraco-Pulmonary Department, National Cancer Institute, 80131 Napoli, Italy \\ ${ }^{6}$ Cellular Biology and Biotherapy, National Cancer Institute, 80131 Napoli, Italy \\ ${ }^{7}$ Centro di Ricerche Oncologiche di Mercogliano (CROM), 83013 Mercogliano, Italy
}

Correspondence should be addressed to Alessandro Morabito, alessandromorabito1@virgilio.it

Received 17 December 2010; Accepted 15 March 2011

Academic Editor: Cesare Gridelli

Copyright (C) 2011 Raffaele Costanzo et al. This is an open access article distributed under the Creative Commons Attribution License, which permits unrestricted use, distribution, and reproduction in any medium, provided the original work is properly cited.

\begin{abstract}
Gefitinib is an oral, reversible, tyrosine kinase inhibitor of epidermal growth factor receptor (EGFR) that plays a key role in the biology of non small cell lung cancer (NSCLC). Phase I studies indicated that the recommended dose of gefitinib was $250 \mathrm{mg} / \mathrm{day}$. Rash, diarrhea, and nausea were the most common adverse events. The positive results obtained in early phase 2 clinical trials with gefitinib were not confirmed in large phase 3 trials in unselected patients with advanced NSCLC. The subsequent discovery that the presence of somatic mutations in the kinase domain of EGFR strongly correlates with increased responsiveness to EGFR tyrosine kinase inhibitors prompted phase 2 and 3 trials with gefitinib in the first line-treatment of EGFR-mutated NSCLC. The results of these trials have demonstrated the efficacy of gefitinib that can be now considered as the standard first-line treatment of patients with advanced NSCLC harbouring activating EGFR mutations.
\end{abstract}

\section{Introduction}

Gefitinib (ZD1839, Iressa) is an orally administered, reversible tyrosine kinase inhibitor (TKIs) of epidermal growth factor receptor (EGFR), belonging to the smallmolecule class (quinazoline-derivative molecule) [1]. The EGFR family includes four different tyrosine kinase receptors: EGFR (ErbB-1), ErbB-2, ErbB-3, and ErbB-4 [2]. Each of these proteins has an extracellular ligand-binding domain, a single hydrophobic transmembrane domain and a cytoplasmic tyrosine kinase-containing domain. The receptors of the ErbB family are activated following binding to peptide growth factors of the EGF-family. Upon ligand binding, the ErbB receptors form either homo- or heterodimers and, following dimerization, auto- and transphosphorylation in tyrosine residues of the ErbB receptors occurs [3]. EGFR signaling plays a key role in promoting the growth and survival of various types of solid tumors, including non small cell lung cancer (NSCLC) $[4,5]$.

Gefitinib has an inhibitory effect both on the autophosphorylation and downstream signaling, competing reversibly with the adenosine triphosphate (ATP) for the catalytic domain of EGFR. In vitro studies indicated that gefitinib potently inhibited EGFR tyrosine kinase activity at low concentrations that did not significantly affect other kinases tested [6]. In vivo studies showed that gefitinib had a favourable tolerability profile and an antitumor activity in various xenograft models and enhanced the antitumor activity of a variety of cytotoxic drugs, including platinum compounds $[7,8]$. Gefitinib was well tolerated in healthy volunteers and showed a terminal half-life of 28 hours, supporting the once-daily oral administration [9]. 
This paper focuses on the clinical development of gefitinib in NSCLC, discussing the causes of its failure in unselected NSCLC patients and summarizing the available evidence coming from the randomized phase 3 trials that support the use of gefitinib as the standard first line treatment of patients with advanced NSCLC harbouring EGFR mutations.

\section{Phase I Clinical Studies}

Gefitinib has been evaluated as single agent in four phase 1 clinical trials, including patients with advanced refractory solid tumors. In the first study, conducted in UK and USA, gefitinib was administered once daily for 14 consecutive days, followed by 14 days off treatment [10]. Dose escalation started at $50 \mathrm{mg}$ and continued to $925 \mathrm{mg}$ or until consistent dose-limiting toxicity (DLT). Sixty-four patients were entered at eight dose levels. The most frequent dose-related grade 1 and 2 adverse events were acne-like rash, nausea, and diarrhea. Three of 9 patients treated at $700 \mathrm{mg} /$ day developed DLT (reversible grade 3 diarrhea). Four of 16 patients with NSCLC had partial responses (observed from 300 to $700 \mathrm{mg}$ /day). In the second study, including 88 patients in Europe and Australia, gefitinib was administered at dose ranging from 150 to $1000 \mathrm{mg} /$ day in 28-day cycles to patients with either advanced non small cell lung, ovarian, head and neck, prostate, or colorectal cancer [11]. At $1000 \mathrm{mg} /$ day, 5 of 12 patients experienced DLT (grade 3 diarrhea in four patients and grade 3 somnolence in one patient). The most frequent adverse events were acne-like rash (64\%) and diarrhea $(47 \%)$, which were generally mild (grade $1 / 2$ ) and reversible on cessation of treatment. Nineteen patients had stable disease and received gefitinib for $>3$ months. In the third study, conducted in USA, 71 patients were enrolled at seven dose levels (ranging from 150 to $1000 \mathrm{mg} /$ day in 28day cycles) and most had NSCLC $(n=39)$ [12]. Diarrhea and rash, the primary DLTs, occurred at $800 \mathrm{mg}$. Frequent treatment-related grade 1-2 adverse events were diarrhea (55\%), asthenia (44\%), and acne-like follicular rash (46\%). At doses $>800 \mathrm{mg}, 45 \%$ of patients required dose reductions. One partial response and 6 prolonged stable disease were observed in patients with NSCLC. The fourth phase 1 study investigated the tolerability and toxicity of gefitinib in Japanese patients with solid tumors [13]. Thirty-one patients were included and received oral gefitinib on 14 consecutive days, every 28 days. Dose escalation was from $50 \mathrm{mg} /$ day to a maximum of $925 \mathrm{mg} /$ day or DLT. The most frequent adverse events were an acne-like rash and gastrointestinal side effects. Two of 6 patients at $700 \mathrm{mg} /$ day had DLT; no further dose escalation occurred. A partial response was observed in 5 of the 23 patients with NSCLC (duration 35-361 days) over a range of doses (225-700 $\mathrm{mg} /$ day), and 7 patients with various tumors had disease stabilization. Therefore, gefitinib showed a favourable tolerability profile and antitumor activity also in Japanese patients. Moreover, pharmacokinetic analyses from all these studies confirmed the feasibility of the once daily schedule.

The preclinical evidence of synergism between gefitinib and chemotherapy provided the rationale for a feasibility study designed to assess the tolerability and antitumor activity of the combination of two doses of gefitinib (250 and $500 \mathrm{mg} / \mathrm{day}$ ), gemcitabine and cisplatin (at standard doses) in chemotherapy-naïve patients with advanced or metastatic solid tumors, and to assess whether there was a pharmacokinetic interaction between these drugs when administered concurrently [14]. Eighteen patients were entered, 9 at each gefitinib dose level. Two patients developed DLT: one grade 3 convulsion $(250 \mathrm{mg} /$ day dose group) and one grade 3 rash $(500 \mathrm{mg} /$ day dose group). The most common grade $3 / 4$ adverse events were vomiting (7 patients), asthenia (6 patients), thrombocytopenia (6 patients), diarrhea (5 patients), and anorexia (5 patients). Pharmacokinetic analyses showed no apparent pharmacokinetic interaction between gefitinib and cisplatin or gemcitabine, with the exception of a possible small increase in the geometric mean exposure to gemcitabine seen on day 8 of therapy when given alone with the higher dose of gefitinib. Of 10 evaluable patients with NSCLC, 5 had confirmed partial response, 4 had stable disease and 1 had progressive disease.

\section{Development of Gefitinib in "Unselected" Patients}

3.1. Phase II Clinical Studies. Two randomized phase 2 clinical studies evaluated the safety and the activity of two doses of gefitinib ( $250 \mathrm{mg}$ or $500 \mathrm{mg}$ ) as second- or third-line therapy of NSCLC patients (IDEAL 1 and IDEAL 2) $[15,16]$. The IDEAL-1 (Iressa Dose Evaluation in Advanced Lung cancer) study recruited 210 patients who were pretreated with one or two chemotherapy regimens, at least one containing platinum [15]. The IDEAL-2 study included 221 patients who were pretreated with two or more regimens containing platinum and docetaxel [16]. In both studies, the two doses of gefitinib produced similar results in terms of objective responses (approximately 20\% in IDEAL-1 and $10 \%$ in IDEAL-2), disease control rate (about $50 \%$ in IDEAL 1 and 40\% in IDEAL 2), and overall survival (about 8 months in IDEAL 1 and 7 months in IDEAL 2). Overall, the incidence of toxic effects, including skin rash and diarrhea, was lower in patients treated with $250 \mathrm{mg} /$ day as compared with patients treated with $500 \mathrm{mg} /$ day. These results led to choosing the lower dose for subsequent development of the drug in NSCLC. In both trials, an attempt has been made to identify predictive factors for objective response to gefitinib. In the IDEAL-1 study, a multivariate analysis showed that performance status, previous immuno/hormonal treatment, histology, and female gender were significantly associated with a higher response rate, while in the IDEAL-2 study only female gender was significantly predictive of response to gefitinib. The promising results of these trials led, in 2003, the Food and Drug Administration (FDA) to grant an accelerated approval for gefitinib as monotherapy treatment for patients with locally advanced or metastatic NSCLC after failure of both platinum-based and docetaxel chemotherapies.

The results of other phase 2 studies conducted with gefitinib as single agent in unselected patients with advanced NSCLC are summarized in Table 1 [15-23]. 
TABLe 1: Phase II clinical trials with Gefitinib as single agent in "unselected” NSCLC.

\begin{tabular}{|c|c|c|c|c|c|c|}
\hline Author (yr) & Setting & Design & Pts & Gefitinib dose & Results & Toxicity \\
\hline $\begin{array}{l}\text { Fukuoka et al. } \\
(2003)[15]\end{array}$ & $\begin{array}{l}\text { Pretreated with } \\
1-2 \text { lines }\end{array}$ & $\begin{array}{l}\text { Randomized } \\
\text { phase } 2\end{array}$ & 210 & $\begin{array}{l}250 \mathrm{mg} \text { versus } \\
500 \mathrm{mg}\end{array}$ & $\begin{array}{l}\text { RR: } 18.4 \%(250 \mathrm{mg}) \text { versus } \\
19 \%(500 \mathrm{mg}) ; \text { PFS: } 2.7 \\
\text { versus } 2.8 \text { months }\end{array}$ & $\begin{array}{l}\text { Diarrhea, rash and other } \\
\text { skin events }\end{array}$ \\
\hline $\begin{array}{l}\text { Kris et al. (2003) } \\
{[16]}\end{array}$ & $\begin{array}{l}\text { Pretreated with } \\
2-3 \text { lines }\end{array}$ & $\begin{array}{l}\text { Randomized } \\
\text { phase } 2\end{array}$ & 221 & $\begin{array}{l}250 \mathrm{mg} \text { versus } \\
500 \mathrm{mg}\end{array}$ & $\begin{array}{l}\text { RR: } 12 \text { versus 9\%; OS: } 7 \\
\text { versus } 6 \text { months }\end{array}$ & $\begin{array}{l}\text { Diarrhea, rash and other } \\
\text { skin events }\end{array}$ \\
\hline $\begin{array}{l}\text { D'Addario et al. } \\
\text { (2008) [17] }\end{array}$ & Chemonaive & $\begin{array}{l}\text { Phase 2, } \\
\text { single arm }\end{array}$ & 63 & $250 \mathrm{mg}$ & $\begin{array}{l}\text { RR: } 9.5 \% \text {; DSR at } 12 \\
\text { weeks: } 38 \%\end{array}$ & $\begin{array}{l}\text { Rash and other skin } \\
\text { events, hepatotoxicity }\end{array}$ \\
\hline $\begin{array}{l}\text { Wan et al. } \\
(2006)[18]\end{array}$ & $\begin{array}{l}\text { Not fit for } \\
\text { chemo or } \\
\text { pretreated }\end{array}$ & $\begin{array}{l}\text { Phase } 2 \text {, } \\
\text { single arm }\end{array}$ & 151 & $250 \mathrm{mg}$ & $\begin{array}{l}\text { RR: } 29.8 \% \text {; TTP: } 12 \\
\text { months; } 1 \text { yr OS: } 57 \%\end{array}$ & $\begin{array}{l}\text { Rash, diarrhea, } \\
\text { nasal/oral mucosa } \\
\text { bleeding }\end{array}$ \\
\hline $\begin{array}{l}\text { Lin et al. (2006) } \\
{[19]}\end{array}$ & Chemonaive & $\begin{array}{l}\text { Phase } 2 \text {, } \\
\text { single arm }\end{array}$ & 53 & $250 \mathrm{mg}$ & $\begin{array}{l}\text { RR: } 32.1 \% \text {; TP: } 12 \\
\text { months; OS: } 15.3 \text { months; } \\
1 \text { yr OS: } 57 \%\end{array}$ & $\begin{array}{l}\text { Skin toxicity, diarrhea, } \\
\text { nail change, ILD }\end{array}$ \\
\hline $\begin{array}{l}\text { Niho et al. } \\
(2006)[20]\end{array}$ & Chemonaive & $\begin{array}{l}\text { Phase } 2 \text {, } \\
\text { single arm }\end{array}$ & 42 & $250 \mathrm{mg}$ & $\begin{array}{l}\text { RR: } 30 \% \text {; OS: } 13.9 \text { months; } \\
1 \text { yr OS: } 55 \%\end{array}$ & $\begin{array}{l}\text { Rash and other skin } \\
\text { events, ILD }\end{array}$ \\
\hline $\begin{array}{l}\text { Reck et al. } \\
(2006)[21]\end{array}$ & Chemonaive & $\begin{array}{l}\text { Phase } 2 \text {, } \\
\text { single arm }\end{array}$ & 58 & $250 \mathrm{mg}$ & $\begin{array}{l}\text { RR: } 5 \% \text {; TTP: } 1.8 \text { months; } \\
\text { OS: } 7.3 \text { months }\end{array}$ & $\begin{array}{l}\text { Skin toxicity and } \\
\text { diarrhea }\end{array}$ \\
\hline $\begin{array}{l}\text { Suzuki et al. } \\
(2006)[22]\end{array}$ & Chemonaive & $\begin{array}{l}\text { Phase } 2 \text {, } \\
\text { single arm }\end{array}$ & 34 & $250 \mathrm{mg}$ & $\begin{array}{l}\text { RR: } 26.5 \% \text {; OS: } 14 \text { months; } \\
1 \text { yr OS: } 58.2 \%\end{array}$ & $\begin{array}{l}\text { Rash, fatigue, } \\
\text { hepatotoxicity }\end{array}$ \\
\hline $\begin{array}{l}\text { Spigel et al. } \\
(2005) \text { [23] }\end{array}$ & Chemonaive & $\begin{array}{l}\text { Phase } 2 \text {, } \\
\text { single arm }\end{array}$ & 70 & $250 \mathrm{mg}$ & $\begin{array}{l}\text { RR: } 4 \% \text {; TTP: } 3.7 \text { months; } \\
\text { OS: } 6.3 \text { months; } 1 \text { yr OS: } \\
24 \%\end{array}$ & Rash and diarrhea \\
\hline
\end{tabular}

RR: response rate; PFS: progression-free survival; OS: overall survival; DSR: disease stabilization rate; TTP: time to progression; ILD: interstitial lung disease.

3.2. Phase III Clinical Studies in First-Line Therapy. The encouraging results obtained in early clinical trials and the preclinical evidence of synergism between gefitinib and chemotherapy prompted two large randomized phase 3 clinical trials examining the role of gefitinib in combination with standard chemotherapy (cisplatin plus gemcitabine in INTACT-1 and carboplatin plus paclitaxel in INTACT-2) for the first line treatment of advanced NSCLC [24, 25]. Both of these studies failed to demonstrate any advantage in overall survival for patients treated with chemotherapy in combination with gefitinib. Moreover, subgroups analyses of predictive factors of sensitivity to gefitinib did not demonstrate any survival advantage for specific subgroups when gefitinib was added to chemotherapy. Negative results were similarly observed with the combination of another tyrosine kinase inhibitor, erlotinib, with chemotherapy (TALENT and TRIBUTE studies) [26, 27]. Several explanations regarding the lack of an additive effect between tyrosine kinase inhibitors and chemotherapy have been proposed: a mechanistic interaction between gefitinib or erlotinib and chemotherapy, for which the antiproliferative effects of anti-EGFR agents may render tumor cells less sensitive to cytotoxic agents, as suggested by preclinical studies; the possibility that patients who benefit from EGFR-targeted treatments are the same who likely respond to chemotherapy: in this case, the effect of tyrosine kinase inhibitors can be masked by the effect of chemotherapy; finally, the lack of patient selection based on the expression of EGFR [28].

Because no additive effect was observed by administering gefitinib in combination with chemotherapy, a phase 3 trial was conducted to evaluate the efficacy of a sequential strategy, with gefitinib given after first line platinumdoublet chemotherapy for NSCLC, which might have avoided problems of drug interference or antagonism [29]. Unfortunately, sequential gefitinib therapy after three cycles of standard platinum doublet chemotherapy showed no survival benefit over platinum doublet chemotherapy up to six cycles (HR 0.86, 95\%CI 0.72-1.03, $P=.11$ ), although sequential gefitinib was associated with significantly prolonged progression-free survival (HR 0.68, 95\%CI 0.57-0.80; $P<$.001). An exploratory subset analysis demonstrated a possible survival prolongation for sequential therapy of gefitinib, for patients with adenocarcinoma (HR $0.79,95 \% \mathrm{CI}$ $0.65-0.98, P=.03$ ).

Table 2 summarizes the results of the randomized clinical trials with gefitinib in first- and second-line therapy, in locally advanced disease and adjuvant setting and in special populations [24, 25, 29-38].

3.3. Phase III Clinical Studies in Second-Line Therapy. A multicenter phase 3 study compared gefitinib as monotherapy at the dose of $250 \mathrm{mg} /$ day to placebo in 1692 pretreated patients with NSCLC [30]. Patients treated with gefitinib reported significantly higher response rate ( $8 \%$ versus $1.3 \%)$ and longer time to treatment failure (3.0 versus 2.6 months). However, treatment with gefitinib was not associated with significant improvement in survival in the overall population (5.6 versus 5.1 months in the gefitinib and placebo arms, resp.) nor in the subgroup of patients with adenocarcinoma. There was pronounced heterogeneity in survival outcomes between groups of patients, with some evidence of benefit among never-smokers (median survival of 8.9 versus 6.1 


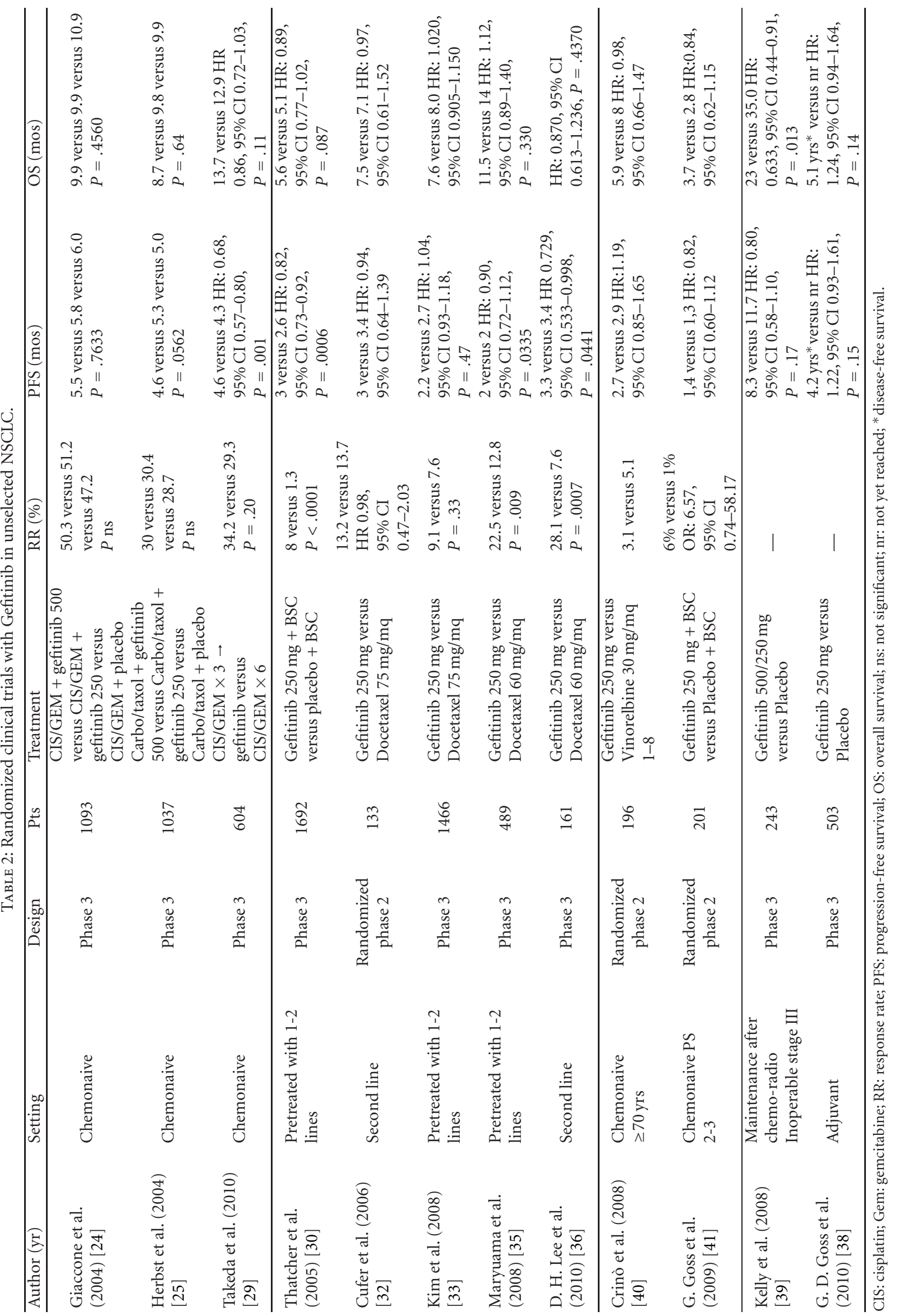


months; HR 0.67 ; 95\% CI $0.49-0.92, P=.012)$ and Asian ethnicity (9.5 versus 5.5 months; HR 0.66; 95\% CI $0.48-0.91, P=.01)$. Explanations of the negative results of this trial could be the large number of chemotherapy refractory patients (90\%), a suboptimal dose of gefitinib and the lack of selection based on potential molecular markers, associated with clinical outcome. In addition, exploratory biomarker analyses, including the assessment of EGFR gene copy number by FISH, EGFR and p-AKT protein expression by IHC, EGFR, K-RAS and D-RAF mutational status, showed a trend towards a better survival outcome for gefitinib in patients with high EGFR-gene-copy number (HR 0.61 for high copy number and HR 1.16 for low copy number, $P=.045$ ), while patients with EGFR mutations obtained higher RR than wild-type patients (37.5\% versus $2.6 \%)$ [31]. No relationship was observed between p-AKT protein expression and survival outcome. On the basis of the lack of survival benefit in the ISEL study, in 2005 the FDA restricted the use of gefitinib to patients continuing to benefit from treatment already initiated or participating in clinical trials.

Four randomized trials compared gefitinib versus docetaxel as a second-line therapy of advanced NSCLC patients.

An open-label randomized phase 2 study (SIGN trialSecond line Indication of Gefitinib in NSCLC) compared gefitinib $(250 \mathrm{mg} /$ day $)$ with docetaxel $(75 \mathrm{mg} / \mathrm{mq}$ every 3 weeks) in 135 patients with advanced pretreated NSCLC [32]. Primary objective of this trial was symptom improvement using the FACT-L questionnaire. Gefitinib and docetaxel showed similar activity (symptom improvement rates of $36 \%$ and $26 \%$, response rate of $13.2 \%$ and $13.7 \%$, median progression-free survival of 3 and 3.4 months, median overall survival of 7.5 and 7.1 months, with quality of life improvement rates of $33.8 \%$ and $26 \%$ for gefitinib and docetaxel, resp.). However, gefitinib had a more favorable tolerability profile than docetaxel (adverse events of all grades: $51.5 \%$ versus $78.9 \%$; grade $3-4: 8.8 \%$ versus $25.4 \%$ ).

The INTEREST trial was the largest study comparing gefitinib to docetaxel as second- or third-line therapy in 1466 patients with advanced NSCLC treated with prior platinumbased chemotherapy [33]. The coprimary endpoints were the noninferiority of gefitinib in comparison with docetaxel in terms of overall survival in the total population and the superiority in patients expressing a high EGFR gene copy number. The study demonstrated the noninferiority of gefitinib (OS 7.6 versus 8.0 months, with a 1-year survival of $32 \%$ versus $34 \%$, in the gefitinib and docetaxel arms, resp., HR 1.02, 96\% CI 0.905-1.150, meeting the pre-defined non inferiority criterion of 1.154), while failed to demonstrate the superiority of gefitinib in the subgroup of 174 patients with high EGFR gene copy number: in this setting, median survival was 8.4 months in the gefitinib group and 7.5 months in the docetaxel group, and 1-year survival was 32 and 35\%, respectively (HR 1.09; 95\% CI 0.78-1.151, $P=$ $.620)$. The most common adverse events in the gefitinib group were skin reactions (49\% versus 10\%) and diarrhea (35\% versus $25 \%$ ), whereas in docetaxel group neutropenia ( $5 \%$ versus $74 \%$ ), asthenia ( $25 \%$ versus $47 \%$ ), and alopecia (3\% versus $36 \%$ ). Significantly more patients had sustained clinically relevant improvement in quality of life with gefitinib than with docetaxel, as assessed by FACT-L total score (OR 1.99, 95\% CI 1.42-2.79; $P<.0001$ ) and the FACTL-TOI (OR 1.82, 95\%CI 1.23-2.69; $P=.0026$ ). Similar proportions of patients had improvements in lung cancer symptoms (FACT-L LCS) with gefitinib and docetaxel (OR $1.29,95 \%$ CI $0.93-1.79 ; P=.013)$. Moreover, a biomarkers analysis was conducted in this trial on 453 patients (31\%) who had tissue samples evaluable for at least one biomarker (EGFR copy number by fluorescent in situ hybridization, EGFR protein expression by immunohistochemistry, and EGFR and KRAS mutations) and showed no difference in overall survival between treatments for any biomarker [34]. However, notably, among patients with EGFR mutationpositive tumors, PFS was longer (HR 0.16; 95\% CI $0.05-$ $0.49, P=.001)$ and objective response was higher $(42.1 \%$ versus $9.8 \%$ ) for gefitinib as compared to docetaxel. Overall survival was longer in patients with EGFR mutation-positive tumors in both gefitinib and docetaxel subgroups (median survival 14.2 and 16.6 months, resp.) than in the overall population (7.6 and 8.0 months, resp.) and in the population with wild-type EGFR (6.4 and 6.0 months, resp.), but there was no difference between treatments. Finally, exploratory analyses showed no difference between patients with high and low EGFR copy number within the gefitinib arm (high versus low $\mathrm{HR}, 1.02,95 \% \mathrm{CI} 0.74-1.41, P=.914$ ) and no significant differences in survival outcome between the study arms according to KRAS mutation status.

Two further randomized phase 3 clinical trials (conducted in Japan and Korea, resp.) compared gefitinib versus docetaxel in patients with locally advanced or metastatic NSCLC, pretreated with one or two chemotherapy regimens $[35,36]$. The Japanese trial did not meet the primary objective (non inferiority of gefitinib versus docetaxel) in terms of overall survival (11.5 months for gefitinib versus 14 months for docetaxel), although fewer severe adverse events $(40.6 \%$ versus $81.6 \%)$ and benefits in terms of quality of life improvement occurred with gefitinib compared with docetaxel [35]. In the Korean study, gefitinib improved significantly objective response rate $(28.1$ versus $7.6 \%)$ and PFS (HR $0.73,90 \%$ CI $0.53-0.98, P=.0441$ ) than docetaxel [36]. However, no differences were observed in terms of OS (14.1 versus 12.2 months in the gefitinib and docetaxel arms, resp.) and quality of life or symptom improvement rates. A meta-analysis of the randomized clinical trials comparing gefitinib to docetaxel was presented at 2009 ASCO Meeting and showed similar overall and progressionfree survival between the two drugs and superior response rate with gefitinib [37]. Therefore, given the similar efficacy demonstrated by gefitinib, its favorable tolerability profile, the quality of life benefits, and the oral administration, the Authors concluded that gefitinib has a favorable benefitrisk profile compared with docetaxel in a broad pretreated advanced NSCLC patient population.

3.4. Phase III Clinical Studies in Adjuvant and Locally Advanced Setting. A single phase 3 trial of adjuvant gefitinib has been conducted to date (the BR.19 trial), starting in the early 2000s, when a great enthusiasm existed for exploring the potential of this drug in NSCLC treatment [38]. 
In the BR.19 trial, patients with completely resected stage IB to IIIA NSCLC were randomly assigned to receive daily gefitinib $250 \mathrm{mg}$ or placebo, for two years. They could also receive adjuvant chemotherapy as appropriate. The primary end-point was overall survival. The study planned to enrol 1160 patients, but it was stopped prematurely in 2005, following the negative results of the ISEL study [30] and the SWOG S0023 trials [39]. At the time of study closure, 503 patients had been enrolled. Data were presented at 2010 ASCO Annual Meeting. Median age of patients was $67 ; 54 \%$ were male, $54 \%$ PS 0 and most of them were ever smoker $(89 \%)$; most of tumors were adenocarcinoma (59\%); only $17 \%$ of patients received chemotherapy. Median followup was 4.7 years. Median time on treatment was 4.8 months in both arms. Differences were not significant for both overall survival ( $\mathrm{HR} 1.24 ; 95 \%$ CI $0.94-1.64 ; P=$ .14 ) and disease-free survival (HR 1.22, 95\% CI 0.93-1.61; $P=.15)$, with a negative trend for gefitinib treatment. The toxicity analysis excluded the possibility of attributing this disadvantage to a higher incidence of fatal toxicity in the gefitinib arm. Preplanned subgroup analyses according to EGFR mutational status (357 evaluable patients, 76 of whom with mutation) demonstrated no benefit for gefitinib treatment in both wild-type and mutant NSCLC patients, with a more evident negative trend just in patients with EGFR mutations (HR 1.58, 95\% CI 0.83-3.00; $P=.16$ ). Although all the comparisons have weak power due to the small number of the patients, these results are very striking and preclude the use of adjuvant gefitinib outside from clinical trials.

The above-mentioned SWOG S0023 trial [39] compared maintenance gefitinib to placebo after concurrent chemoradiotherapy and docetaxel consolidation in inoperable stage IIIA and IIIB NSCLC patients. Overall survival was the primary end-point. This study also closed prematurely, on the recommendation of an unplanned interim analysis that was prompted by the results of the ISEL trial. Of the 571 eligible patients registered at the time of the interim analysis (against the 840 planned), 234 were randomized to receive gefitinib $500 \mathrm{mg}$ or placebo, daily for five years. The interim analysis of this study showed that the hypothesized alternative of a 33\% improvement in survival with gefitinib over placebo was ruled out with a one-sided $P=.0015$. Updated results, after a median followup of 27 months, were successively published, showing that patients receiving gefitinib had a worse survival than patients on placebo, with a median survival of 23 compared with 35 months (HR 0.63, 95\% CI 0.44-0.91; $P=.013)$. As in the BR.19 trial, the analysis of cancer-related and toxic death revealed that the inferior survival was due to tumor progression and not to gefitinib toxicity. Unfortunately, molecular features of the tumors, including EGFR mutations, were not recorded in this study. The detrimental effect of maintenance gefitinib after optimal cytoreduction with chemoradiotherapy in stage III NSCLC reported by the S0023 trial excludes the use of the drug in this setting of disease.

The evidence coming from these two randomized trials do not support the use of gefitinib in the localized stages of NSCLC patients, even with tumors carrying EGFR mutations. The intrathoracic disease could have a different biologic behavior that should be further explored.

3.5. Randomized Clinical Studies in Special Populations. In consideration of its good toxicity profile, gefitinib has been tested as an alternative to a single-agent chemotherapy in elderly and poor performance status (PS) NCSLC patients. A randomized phase II trial was conducted by Crinò et al. with gefitinib ( $250 \mathrm{mg}$ daily) versus vinorelbine in 196 untreated elderly ( $\geq 70$ years) NSCLC patients [40]. The trial was designed to determine the superiority of gefitinib versus vinorelbine in terms of progression-free survival. The results showed no statistical difference in progressionfree survival (2.7 versus 2.9 months, HR 1.19, 95\% CI, 0.85-1.65, $P=.310$ ), overall survival (5.9 versus 8.0 months; HR 0.98, 95\% CI, 0.66-1.47), and response rate (3.1 versus $5.1 \%$ ) between gefitinib and vinorelbine, respectively. However, gefitinib showed a better toxicity profile. Most of the enrolled patients were male (77\%), smokers (82\%), and with squamous cell carcinoma, thus without clinical features conferring sensitivity to gefitinib, and this may explain the low percentage of responders in this study.

Goss et al. compared gefitinib to BSC in 201 untreated NCSLC patients with PS $\geq 2$, not eligible for chemotherapy, in a randomized phase II trial [41]. Primary endpoint was PFS and, nevertheless the results showed no statistical difference, there was a trend toward improved progressionfree survival (HR 0.82, 95\% CI, 0.60-1.12, $P=.217$ ), overall survival (HR 0.84, 95\% CI, 0.62-1.15, $P=.272$ ) and response rate (6\% versus $1 \%$ placebo) in favor of gefitinib.

\section{Development of Gefitinib in "Selected" Patients}

4.1. Phase II Clinical Studies. The recent discovery that some somatic mutations in the tyrosine kinase domain of the EGFR gene are associated with a high response to EGFR tyrosine kinase inhibitors in NSCLC highlighted the need for patient selection through molecular screening $[42,43]$.

Several phase 2 studies showed a high response rate (55-90\%) and a prolonged progression-free survival (of approximately 9 months) with first-line gefitinib in Asiatic patients selected on the basis of the presence of activating EGFR gene mutations [44-56]. The results of these studies are summarized in Table 3. Yang and colleagues observed in 43 patients with exon 19 deletions and L858R mutations a response rate of $95 \%$ and $73.9 \%$ and a progressionfree survival of 8.9 and 9.1 months, respectively [46]. The iTARGET trial selected chemo-naïve patients with nonsquamous histology who had one or more clinical characteristics associated with activating EGFR mutations, such as low or never smoking history, adenocarcinoma histology, female gender, and East Asian ethnicity [47]. In this study, mutations were identified in $35 \%$ of patients and 31 patients received gefitinib: the response rate was $55 \%$, the median progression-free survival was 9.2 months, and overall survival was 17.5 months. Actually, the response rate was $78 \%$ and $59 \%$ for patients carrying L858R mutation and exon 19 deletion, respectively, which are activating 
TAвLE 3: Phase II trials with Gefitinib as single agent in "selected” patients with NSCLC.

\begin{tabular}{|c|c|c|c|c|c|}
\hline Author (yr) & Setting & Pts & Treatment & Results & Toxicity \\
\hline $\begin{array}{l}\text { Asahina et al. (2006) } \\
\text { [44] }\end{array}$ & $\begin{array}{l}\text { Chemonaive, EGFR } \\
\text { mutation }\end{array}$ & 16 & Gefitinib $250 \mathrm{mg}$ & $\begin{array}{l}\text { RR: } 75 \% \text {; PFS: } 8.9 \text { months, } \\
1 \text { yr OS: } 88 \%\end{array}$ & Rash, hepatotoxicity \\
\hline $\begin{array}{l}\text { Inoue et al. (2006) } \\
\text { [45] }\end{array}$ & $\begin{array}{l}\text { Chemonaive, EGFR } \\
\text { mutation }\end{array}$ & 16 & Gefitinib $250 \mathrm{mg}$ & $\begin{array}{l}\text { RR: } 75 \% \text {; PFS: } 9.7 \text { months; } \\
1 \text { yr OS: } 88 \%\end{array}$ & Skin toxicity, stomatitis, diarrhea \\
\hline Yang et al. (2008) [46] & $\begin{array}{l}\text { Chemonaive, EGFR } \\
\text { mutation }\end{array}$ & 55 & Gefitinib $250 \mathrm{mg}$ & $\begin{array}{l}\text { RR: } 84.2 \% \text {; PFS: } 8.9 \\
\text { months, OS: } 24 \text { months }\end{array}$ & $\begin{array}{l}\text { Skin toxicity, hepatotoxicity, } \\
\text { diarrhea }\end{array}$ \\
\hline $\begin{array}{l}\text { Sequist et al. (2008) } \\
\text { [47] }\end{array}$ & $\begin{array}{l}\text { Chemonaive, EGFR } \\
\text { mutation }\end{array}$ & 31 & Gefitinib $250 \mathrm{mg}$ & $\begin{array}{l}\text { RR: } 55 \% \text {; PFS: } 9.2 \text { months, } \\
\text { OS: } 17.5 \text { months }\end{array}$ & $\begin{array}{l}\text { Skin toxicity, diarrhea, nausea, } \\
\text { fatigue }\end{array}$ \\
\hline $\begin{array}{l}\text { Sutani et al. (2006) } \\
{[48]}\end{array}$ & $\begin{array}{l}\text { 1st-2nd line, EGFR } \\
\text { mutation }\end{array}$ & 27 & Gefitinib $250 \mathrm{mg}$ & $\begin{array}{l}\text { RR: } 78 \% \text {; PFS: } 9.4 \text { months, } \\
\text { OS: } 15.4 \text { months }\end{array}$ & Diarrhea, skin toxicity \\
\hline $\begin{array}{l}\text { Yoshida et al. (2007) } \\
\text { [49] }\end{array}$ & $\begin{array}{l}\text { Chemonaive, EGFR } \\
\text { mutation }\end{array}$ & 21 & Gefitinib $250 \mathrm{mg}$ & RR: 90\%; TTP: 7.7 months & $\begin{array}{l}\text { Skin toxicity, diarrhea, } \\
\text { hepatotoxicity }\end{array}$ \\
\hline $\begin{array}{l}\text { Sunaga et al. (2007) } \\
\text { [50] }\end{array}$ & $\begin{array}{l}\text { Chemonaive, EGFR } \\
\text { mutation }\end{array}$ & 19 & Gefitinib $250 \mathrm{mg}$ & $\begin{array}{l}\text { RR: 76\%; DSR: } 90 \% \text {; TTP: } \\
12.9 \text { months }\end{array}$ & Skin toxicity \\
\hline $\begin{array}{l}\text { Tamura et al. (2008) } \\
\text { [51] }\end{array}$ & $\begin{array}{l}\text { Chemonaive, EGFR } \\
\text { mutation }\end{array}$ & 27 & Gefitinib $250 \mathrm{mg}$ & $\begin{array}{l}\text { RR: 75\%; DSR: } 96 \% \text {; PFS: } \\
11.5 \text { months, } 1 \text { yr OS: 79\% }\end{array}$ & $\begin{array}{l}\text { Skin toxicity, hepatotoxicity, } \\
\text { stomatitis, diarrhea }\end{array}$ \\
\hline $\begin{array}{l}\text { Sugio et al. (2009) } \\
\text { [52] }\end{array}$ & $\begin{array}{l}\text { Chemonaive, EGFR } \\
\text { mutation }\end{array}$ & 19 & Gefitinib $250 \mathrm{mg}$ & $\begin{array}{l}\text { RR: } 63.2 \% \text {; PFS } 7.1 \\
\text { months, OS: } 20 \text { months }\end{array}$ & Skin toxicity, nail change \\
\hline $\begin{array}{l}\text { Inoue et al. (2009) } \\
\text { [53] }\end{array}$ & $\begin{array}{l}\text { Chemonaive, EGFR } \\
\text { mutation and poor PS }\end{array}$ & 30 & Gefitinib $250 \mathrm{mg}$ & $\begin{array}{l}\text { RR: } 66 \% \text {, DSR } 90 \% \text {, PFS } \\
6.5 \text { months, OS } 17.8 \\
\text { months, PS improvement } \\
\text { rate: } 79 \%\end{array}$ & $\begin{array}{l}\text { Hepatotoxicity, anemia, skin } \\
\text { toxicity }\end{array}$ \\
\hline $\begin{array}{l}\text { Cappuzzo et al. } \\
(2007)[54]\end{array}$ & $\begin{array}{l}\text { FISH positive or } \\
\text { never smokers }\end{array}$ & 42 & Gefitinib $250 \mathrm{mg}$ & $\begin{array}{l}\text { RR: } 47.6 \% \text {; PFS: } 6.4 \\
\text { months; } 1 \text { y OS: } 64 \% .\end{array}$ & Skin toxicity, diarrhea \\
\hline West et al. (2006) [55] & $\begin{array}{l}\text { Brochoalveolar } \\
\text { carcinoma, 1st-2nd } \\
\text { line }\end{array}$ & 91 & Gefitinib $500 \mathrm{mg}$ & $\begin{array}{l}\text { RR: } 9 \% \text { and OS } 13 \text { months } \\
\text { in } 2 \text { nd line; RR } 17 \% \text { and } \\
\text { OS } 13 \text { months in } 1 \text { st line }\end{array}$ & Skin toxicity, diarrhea \\
\hline $\begin{array}{l}\text { D. H. Lee et al. (2005) } \\
{[56]}\end{array}$ & $\begin{array}{l}\text { Adenocarcinoma and } \\
\text { never smokers }\end{array}$ & 37 & Gefitinib $250 \mathrm{mg}$ & $\begin{array}{l}\text { RR: 69\%; PFS: } 33 \text { weeks; } \\
1 \text { yr OS: } 73 \%\end{array}$ & Skin toxicity, diarrhea \\
\hline
\end{tabular}

RR: response rate; PFS: progression-free survival; OS: overall survival; DSR: disease stabilization rate; TTP: time to progression.

mutations, predictive for response to gefitinib, whereas it was $0 \%$ in patients with atypical mutations. Therefore, this study has demonstrated that genotype-directed EGFR-TKI therapy with gefitinib for patients with previously untreated NSCLC is feasible also in a Western population. Inoue et al. tested gefitinib in a phase II trial in NSCLC patients harbouring EGFR mutations and with poor PS, not eligible for chemotherapy [53]. To note, 22 of 30 patients had very poor PS ( 3 or 4 ). The overall response rate was $66 \%$, with disease stabilization rate of $90 \%$. PS improvement rate was $79 \%$. The median progression-free and overall survival were 6.5 and 17.8 months, respectively. This is the first report indicating that EGFR mutation-positive patients with poor PS can benefit from front line gefitinib treatment. Others phase II trials have selected patients on the basis of clinical, pathological, or molecular features. The ONCOBELL trial enrolled 42 patients who were never smokers or who had evidence of a high EGFR gene copy on FISH and were pAKT positive [54]. The response rate was $47.6 \%$, the median time to progression was $6.4 \%$, and 1-year survival rate was $64.3 \%$. In EGFR-mutated patients (66.8\%), the response rate was $62.5 \%$. The Southwest Oncology Group performed a phase II trial for pretreated $(n=22)$ or untreated $(n=69)$ patients with bronchioalveolar carcinoma [55]. The dose of gefitinib used in this trial was $500 \mathrm{mg} /$ day. The response rate in the pretreated and untreated patients was $9 \%$ and $17 \%$, respectively. Finally, a phase II trial investigated the activity of gefitinib $250 \mathrm{mg}$ daily in 37 chemo-naïve Korean patients with adenocarcinoma and a never-smoking history [56]. The response rate was $69 \%$ with a disease stabilization rate of $81 \%$; median progression-free survival and 1-year survival rate were 33 weeks and $73 \%$, respectively.

4.2. Phase III Clinical Studies. Four randomized phase III clinical trials evaluated the role of gefitinib as first line therapy of patients with advanced NSCLC, selected on the basis of clinical or molecular features (Table 4) [5760]. The first evidence of efficacy of a therapeutic strategy based on an EGFR tyrosine kinase inhibitor as a first-line treatment of patients with advanced NSCLC derived from a large, randomized phase 3 clinical trial conducted in Asian patients, the IPASS study [57]. The IPASS (IRESSA Pan Asia Study) trial randomized 1217 patients with advanced adenocarcinoma, non-smoker or former light smoker, to receive gefitinib, $250 \mathrm{mg}$ daily until progression or unacceptable toxicity, or carboplatin (AUC 5-6) plus paclitaxel $\left(200 \mathrm{mg} / \mathrm{m}^{2}\right)$ for a maximum of 6 cycles. The study met the primary objective (non inferiority of gefitinib) and 
TABLE 4: Phase III trials with Gefitinib in "selected" NSCLC.

\begin{tabular}{|c|c|c|c|c|c|c|c|}
\hline Author (yr) & Study & Setting & Pts & Treatment & RR (\%) & PFS (mos) & OS (mos) \\
\hline \multirow[t]{2}{*}{$\begin{array}{l}\text { Mok et al. } \\
\text { (2009) [57] }\end{array}$} & \multirow[t]{2}{*}{ IPASS } & $\begin{array}{l}\text { 1st line, } \\
\text { clinically } \\
\text { selected }\end{array}$ & 1217 & \multirow[t]{2}{*}{$\begin{array}{l}\text { Gefitinib versus } \\
\text { Carboplatin }+ \\
\text { Paclitaxel }\end{array}$} & $\begin{array}{c}43 \text { versus } 32.3 \\
(P=.0001)\end{array}$ & $\begin{array}{l}5.7 \text { versus } 5.8 \\
\text { HR: } 0.74,95 \% \\
\text { CI: } 0.65-0.85 \text {, } \\
P<.0001\end{array}$ & $\begin{array}{l}18.6 \text { versus } 17.3 \\
\text { HR: } 0.91 \text {, } \\
95 \% \text { CI: } \\
0.76-1.10\end{array}$ \\
\hline & & $\begin{array}{l}\text { Subgroup of } \\
\text { EGFR mutated }\end{array}$ & 261 & & $\begin{array}{c}71.2 \text { versus } \\
47.3 \\
(P<.001)\end{array}$ & $\begin{array}{l}9.5 \text { versus } 6.3 \\
\text { HR: } 0.48,95 \% \\
\text { CI: } 0.36-0.64, \\
P<.001\end{array}$ & $\begin{array}{l}\text { HR: } 0.78,95 \% \\
\text { CI } 0.50-1.20\end{array}$ \\
\hline \multirow[t]{2}{*}{$\begin{array}{l}\text { J. S. Lee et al. } \\
(2009) \text { [58] }\end{array}$} & \multirow[t]{2}{*}{$\begin{array}{c}\text { FIRST } \\
\text { SIGNAL }\end{array}$} & $\begin{array}{l}\text { 1st line, } \\
\text { clinically } \\
\text { selected }\end{array}$ & 309 & $\begin{array}{l}\text { Gefitinib versus } \\
\text { Cisplatin }+ \\
\text { Gemcitabine }\end{array}$ & $\begin{array}{c}53.5 \text { versus } \\
45.3 \\
(P=.153)\end{array}$ & $\begin{array}{l}6.1 \text { versus } 6.6 \\
\text { HR: } 0.813,95 \% \\
\text { CI: } 0.641-1.031 \text {, } \\
P=.044\end{array}$ & $\begin{array}{l}21.3 \text { versus } 23.3 \\
\text { HR: } 1.003 \\
95 \% \text { CI: } \\
0.749-1.343 \\
P=.428\end{array}$ \\
\hline & & $\begin{array}{l}\text { Subgroup of } \\
\text { EGFR mutated }\end{array}$ & 42 & & $\begin{array}{c}84.6 \text { versus } \\
37.5 \\
(P=.002)\end{array}$ & $\begin{array}{l}8.5 \text { versus } 6.7 \\
\text { HR: } 0.613,95 \% \\
\text { CI: } 0.308-1.221 \text {, } \\
P=.084\end{array}$ & $\begin{array}{l}30.6 \text { versus } 26.5 \\
\text { HR: } 0.823,95 \% \\
\text { CI: } 0.352-1.922 \text {, } \\
P=.648\end{array}$ \\
\hline $\begin{array}{l}\text { Mitsudomi et } \\
\text { al. (2010) } \\
{[59]}\end{array}$ & $\begin{array}{c}\text { WJTOG } \\
3405\end{array}$ & $\begin{array}{l}\text { 1st line, EGFR } \\
\text { mutated }\end{array}$ & 172 & $\begin{array}{l}\text { Gefitinib versus } \\
\text { Cisplatin }+ \\
\text { Docetaxel }\end{array}$ & $\begin{array}{c}62.1 \text { versus } \\
32.2 \\
(P<.0001)\end{array}$ & $\begin{array}{l}9.2 \text { versus } 6.3 \\
\text { HR } 0.489,95 \% \\
\text { CI: } 0.336-0.710 \text {, } \\
P<.0001\end{array}$ & $\begin{array}{l}30.9 \text { versus } \mathrm{nr} \\
\text { HR: } 1.638,95 \% \\
\text { CI } 0.749-3.582 \text {, } \\
P=.211\end{array}$ \\
\hline $\begin{array}{l}\text { Maemondo } \\
\text { et al. }(2010) \\
{[60]}\end{array}$ & NEJ002 & $\begin{array}{l}\text { 1st line, EGFR } \\
\text { mutated }\end{array}$ & 230 & $\begin{array}{l}\text { Gefitinib versus } \\
\text { Carboplatin }+ \\
\text { Paclitaxel }\end{array}$ & $\begin{array}{c}73.7 \text { versus } \\
30.7 \\
(P<.001)\end{array}$ & $\begin{array}{l}10.8 \text { versus } 5.4 \\
\text { HR } 0.30,95 \% \\
\text { CI: } 0.22-0.41 \\
P<.001\end{array}$ & $\begin{array}{l}30.5 \text { versus } 23.6 \\
P=.31\end{array}$ \\
\hline
\end{tabular}

RR: response rate; PFS: progression-free survival; OS: overall survival; nr: not reached.

also demonstrated the superiority of gefitinib compared to carboplatin and paclitaxel in terms of progression-free survival in intention-to-treat analysis (HR 0.74, 95\% CI: $0.65-0.85, P=.001)$. Because of the crossing of the curves, the median progression-free survival is similar with both treatments: however, the pattern of progression-free rates favors chemotherapy for the first 6 months and gefitinib for the remaining 16 months. The initial superiority of chemotherapy was attributed to the benefit that the EGFRmutation-negative subgroup received from chemotherapy but not from gefitinib, whereas prolonged progression-free survival in the EGFR-mutation-positive subgroup explained the subsequent improvement favoring gefitinib. Crossing of the curves did not occur in the mutation-positive subgroup or the mutation-negative subgroup. Another important finding of this study was the significant interaction between treatment efficacy and EGFR mutational status. In the subgroup of patients with EGFR mutation (261 of 437 available samples), progression-free survival was significantly longer (HR 0.48 ; 95\% CI 0.36-0.64, $P=.001$ ), and the response rate was significantly higher with gefitinib than with carboplatinpaclitaxel $(71.2 \%$ versus $47.3 \%, P=.001)$. On the contrary, in the mutation-negative subgroup, progression-free survival was significantly shorter (HR 2.85; 95\% CI 2.05-3.98, $P<$ .001 ) and response rate was significantly lower with gefitinib (23.5\% versus $1.1 \%, P=.001)$. Overall survival data were immature, based on only $37.0 \%$ of events, and showed a similar overall survival between the two groups: 18.6 months with gefitinib and 17.3 months with carboplatinpaclitaxel (HR for death in the gefitinib group, 0.91; 95\% CI, 0.76 to 1.10). Final overall survival data confirmed no difference between gefitinib and chemotherapy, in the whole population (18.8 months with gefitinib versus 17.4 months with chemotherapy, HR 0.90, 95\% CI: 0.79-1.02, $P=.11$ ) and in the mutation positive subgroup (HR 1.00, 95\% CI: 0.76-1.33) [61]. Patients in the gefitinib group had a clinically relevant improvement in quality of life, as assessed by FACT-L questionnaire (OR 1.34; 95\% CI 1.06$1.69, P=.01$ ) and by TOI (Trial Outcome Index) scores (OR 1.78; 95\% CI 1.40-2.26; $P<.001$ ). Moreover, gefitinib was associated with a lower rate of grade 3 or 4 adverse events compared to chemotherapy. The incidences of rash or acne, diarrhea, and elevated aminotransferase levels were significantly higher with gefitinib, whereas neurotoxic effects, nausea and vomiting, and hematologic toxic effects were significantly higher with carboplatin-paclitaxel. Interstitial lung disease events (i.e., the acute respiratory distress syndrome, interstitial lung disease, pneumonitis, or radiation pneumonitis) occurred in 16 patients treated with gefitinib $(2.6 \%)$ and in 8 patients treated with chemotherapy (1.4\%).

A second randomized phase 3 clinical trial compared gefitinib (250 mg daily) with cisplatin-gemcitabine as a firstline treatment in 309 Asian, never smokers patients, with advanced adenocarcinoma [58]. The study failed to reach its primary endpoint, overall survival, even if gefitinib allowed the achievement of a favorable response rate: $53.5 \%$ for 
gefitinib versus $45.3 \%$ for chemotherapy (OR 1.385, 95\% CI $0.885-2.167, P=.153)$. The overall mutation rate in this study was $43.8 \%$ : in mutation positive patients, the response rate was $84.6 \%$ for gefitinib versus $37.5 \%$ for chemotherapy $(P=.002)$, while, in mutation negative subgroup, the response rate was $29.9 \%$ for gefitinib versus $51.9 \%$ for chemotherapy $(P=.051)$. Median overall survival and progression-free survival were similar between the two groups. There was some difference in progressionfree survival favoring gefitinib in mutation positive patients (8.5 versus 6.7 months; HR 0.613 , 95\% CI $0.308-1.221$, $P=.0849)$. There was no difference in overall survival by mutation status, both in the overall and EGFR-mutated populations: it could be due to the poststudy use of EGFR TKIs in $80.7 \%$ of chemotherapy arm.

Two randomized phase 3 studies have been performed in Japanese, EGFR-mutated patients with advanced NSCLC, to compare the efficacy of gefitinib versus chemotherapy in the first-line setting. In the open label phase III WJTOG3405 trial, 172 EGFR mutated patients were randomly assigned to receive gefitinib (250 mg daily) or chemotherapy (cisplatin $80 \mathrm{mg} / \mathrm{m}^{2}$ plus docetaxel $60 \mathrm{mg} / \mathrm{m}^{2}$ adminstered every 21 days for three to six cycles) [59]. The primary endpoint was progression-free survival. The study met its endpoint, showing a median progression-free survival of 9.2 months in the gefitinib group versus 6.3 months in the chemotherapy group (HR 0.489, 95\% CI: $0.336-0.710, P=.0001$ ). In this molecularly selected population, progression-free survival curves did not cross, unlike IPASS trial, being the benefit of gefitinib over chemotherapy consistent at any time of treatment. Response rate was $62.1 \%$ and $32.2 \%$ with gefitinib and chemotherapy, respectively $(P<.0001)$. Myelosuppression, alopecia and fatigue were more frequent in the cisplatin-docetaxel group, while skin toxicity, liver dysfunction, and diarrhea in the gefitinib group.

Another prospective phase III study, the NEJ002 Trial, compared gefitinib to chemotherapy with carboplatin and paclitaxel as a first-line treatment in advanced NSCLC patients selected for EGFR mutation [60]. The study was stopped by independent data and safety monitoring committee after the preplanned interim analysis, conducted 4 months after the 200th patient enrolled, because it showed a significant difference in progression-free survival between the two treatment groups. The median progression-free survival was 10.4 months versus 5.5 months for gefitinib and chemotherapy, respectively (HR 0.36, 95\% CI: 0.25-0.51, $P<.001$ ), and the final analysis confirmed these results, showing a median PFS of 10.8 versus 5.4 months for gefitinib and chemotherapy, respectively (HR $0.30,95 \%$ CI $0.22-0.41$, $P<.001)$. The response rate was significantly higher in the gefitinib than chemotherapy arm $(73.7 \%$ versus $30.7 \%$, $P<.001)$. The median progression-free survival and overall survival did not differ significantly between patients with exon 19 deletion and those with L858R point mutation (11.5 months versus 10.8 months, resp.). The overall survival did not differ significantly between the two treatment groups (median survival time and the 2-year survival rate were 30.5 months and $61.4 \%$ for gefitinib group as compared with 23.6 months and $46.7 \%$ for the chemotherapy, resp., $P=.31$ ).
Importantly, among 112 patients who had completed firstline carboplatin-paclitaxel, 106 (94.6\%) received second-line gefitinib and $58.5 \%$ of these patients had a response. The most common adverse events in the gefitinib group were rash and elevated levels of aspartate aminotransferase or alanine aminotransferase and, in the chemotherapy arm, appetite loss, neutropenia, anemia, and sensory neuropathy. Interstitial lung disease was reported in 6 patients $(5.3 \%)$ in the gefitinib arm, with one of these fatal. In general, the incidence of severe toxic effects (NCI-CTC $\geq 3$ ) was significantly higher in the chemotherapy group than in the gefitinib group $(71.7 \%$ versus $41.2 \%, P<.001)$.

Therefore, these both studies confirmed gefitinib to be superior to chemotherapy in terms of response rate and progression-free survival in patients with EGFR mutations.

\section{Ongoing Phase III/IV Studies in NSCLC}

Several phase III/IV studies are currently ongoing with gefitinib in NSCLC in different clinical settings (Table 5).

A double-blind, multicenter, randomized, placebocontrolled phase III study is evaluating the efficacy, safety, and tolerability of gefitinib as a maintenance therapy in 296 patients with locally advanced or metastatic NSCLC (INFORM trial, ClinicalTrials.gov ID: NCT00770588). Patients must have completed 4 cycles of platinum-based first-line doublet chemotherapy without experiencing disease progression or unacceptable toxicity and are randomized to gefitinib or placebo at $1: 1$ ratio. The primary endpoint is progression-free survival; secondary endpoints are overall survival, objective tumor response, quality of life, and safety profile in terms of adverse events.

Another randomized phase III trial is evaluating the efficacy of a maintenance therapy with gefitinib compared with placebo in 600 Japanese patients treated with first-line chemotherapy for stage IIIB or IV NSCLC (ClinicalTrials.gov ID: NCT00144066). The primary aim of the study is to determine if gefitinib improves overall survival of the patients that did not progress on prior first line induction chemotherapy. Secondary objectives are progression-free survival and safety profile.

A phase IV study is investigating the activity and safety of gefitinib as first-line therapy for 100 Caucasian patients with EGFR-positive mutations (ClinicalTrials.gov ID: NCT01203917). The primary endpoint is the objective response rate; secondary endpoints are disease control rate, safety data, and overall survival.

A randomized phase III clinical study will compare gefitinib versus pemetrexed in never-smoker patients with adenocarcinoma histotype, previously treated with platinumbased chemotherapy (ClinicalTrials.gov ID: NCT01066195). The estimated enrollment is of 129 patients, and the main endpoints are progression-free survival, overall survival, objective response rate, and toxicity.

A randomized, open label, phase III study is enrolling 226 East Asian never or light ex-smoker patients with locally advanced or metastatic nonsquamous NSCLC, with the aim to compare first line cisplatin + pemetrexed for 6 cycles 
TABLE 5: Ongoing phase III/IV studies in NSCLC.

\begin{tabular}{|c|c|c|c|c|c|c|}
\hline $\begin{array}{l}\text { Study } \\
\text { phase }\end{array}$ & $\begin{array}{l}\text { Line of } \\
\text { treatment }\end{array}$ & $\begin{array}{l}\text { ClinicalTrials.gov } \\
\text { ID }\end{array}$ & Setting & $\begin{array}{l}\text { Estimated } \\
\text { sample } \\
\text { size (pts) } \\
\end{array}$ & Treatment & $\begin{array}{l}\text { Primary } \\
\text { endpoint }\end{array}$ \\
\hline III & $1 \mathrm{st}$ & NCT00770588 & $\begin{array}{l}\text { Maintenance after first } \\
\text { line platinum-based } \\
\text { chemotherapy }\end{array}$ & 296 & $\begin{array}{l}\text { Gefitinib } 250 \text { mg versus } \\
\text { Placebo }\end{array}$ & $\begin{array}{l}\text { Progression-free } \\
\text { survival }\end{array}$ \\
\hline III & 1 st & NCT00144066 & $\begin{array}{l}\text { Maintenance after first } \\
\text { line platinum-based } \\
\text { chemotherapy }\end{array}$ & 600 & $\begin{array}{l}\text { Gefitinib } 250 \text { mg versus } \\
\text { Placebo }\end{array}$ & Overall survival \\
\hline IV & 1 st & NCT01203917 & Selected Caucasian pts & 100 & Gefitinib $250 \mathrm{mg}$ & $\begin{array}{l}\text { Objective } \\
\text { response rate }\end{array}$ \\
\hline III & $\geq 2$ nd & NCT01066195 & $\begin{array}{l}\text { Never smoker pts with } \\
\text { adenocarcinoma }\end{array}$ & 129 & $\begin{array}{l}\text { Gefitinib } 250 \text { mg versus } \\
\text { Pemetrexed }\end{array}$ & $\begin{array}{l}\text { Progression-free } \\
\text { survival }\end{array}$ \\
\hline III & 1 st & NCT01017874 & Selected East Asian pts & 226 & $\begin{array}{l}\text { Gefitinib alone versus } \\
\text { Cisplatin- } \\
\text { Pemetrexed } \rightarrow \text { Gefitinib }\end{array}$ & $\begin{array}{l}\text { Progression-free } \\
\text { survival }\end{array}$ \\
\hline \multirow[t]{2}{*}{ IV } & 1 st & NCT00173524 & First line Asian pts & 200 & $\begin{array}{l}\text { Gefitinib versus } \\
\text { Platinum-based } \\
\text { chemotherapy }\end{array}$ & $\begin{array}{l}\text { Cost- } \\
\text { effectiveness }\end{array}$ \\
\hline & & & & & Systemic and radiant & \\
\hline III & 1st-2nd & NCT00955695 & $\begin{array}{l}\text { Never smoker } \\
\text { adenocarcinoma pts } \\
\text { treated with } \\
\text { prophylactic cranial } \\
\text { irradiation }\end{array}$ & 242 & $\begin{array}{l}\text { Prophylactic whole brain } \\
\text { radiation therapy during } \\
\text { gefitinib } 250 \mathrm{mg} \text { or } \\
\text { erlotinib } 150 \mathrm{mg}\end{array}$ & $\begin{array}{l}\text { Incidence of } \\
\text { symptomatic } \\
\text { brain metastases }\end{array}$ \\
\hline
\end{tabular}

followed by gefitinib for 6 courses (each of 21 days) versus gefitinib alone for 6 courses (each of 21 days) (ClinicalTrials.gov ID: NCT01017874). Primary endpoint is progression-free survival; secondary endpoints are overall survival, tumor response rate, disease control rate, time to progression, duration of response, and time to worsening of health-related quality of life. The trial should be completed in 2013.

A multicenter randomized phase III study is investigating the efficacy of whole brain radiation therapy compared with observation in preventing brain metastases in 242 patients with advanced NSCLC responding to first- or second-line gefitinib (250 mg/day) or erlotinib (150 mg/day) administered continuatively until disease progression or unacceptable toxicity (ClinicalTrials.gov ID: NCT00955695). Patients must be never smoker, with a diagnosis of adenocarcinoma with the EGFR-positive mutations on exon 19 or 21. Prophylactic cranial irradiation consists of $25 \mathrm{~Gy}$ cumulative dose over 10 fractions. The primary endpoint is the incidence of symptomatic brain metastases. Secondary endpoints are overall survival, progression-free survival, safety, psycho-neurological effects, and quality of life.

A phase IV pharmacoeconomics study will have the objective to analyze the cost-effectiveness and the cost-utility of gefitinib as a first-line treatment for 200 patients affected by stage IIIB or IV NSCLC, compared with the conventional first-line platinum-based chemotherapy (ClinicalTrials.gov ID: NCT00173524).

\section{Discussion and Conclusions}

The development of gefitinib in NSCLC is a clear example of the difficulties in designing and conducting of clinical trials with new molecular-targeted agents and of the uncertainty about predictive factors and selection criteria [62]. Crucial points, regarding the methodology of clinical research with target-based agents, especially for phase 3 trials, are how should patients be selected and which patients are expected to benefit from a targeted agent [63]. The proper characterization of a molecular target that allows the identification of responding versus nonresponding patients to a moleculartargeted agent could have important implications for the design of randomized trials evaluating the efficacy of the drug. In fact, the presence of unrecognized molecular heterogeneity can result in a falsely negative study that could be underpowered and may fail to detect a truly effective new therapy, leading to the rejection of a potentially useful drug [64].

Gefitinib was the first targeted drug that entered into clinical practice for the treatment of lung cancer: however, the positive results obtained in early clinical trials were not confirmed in large phase 3 trials, testing the efficacy of gefitinib in unselected patients with advanced NSCLC and, therefore, the use of gefitinib in clinical practice was stopped for several years.

It has been then shown that the presence of somatic mutations in the kinase domain of EGFR strongly correlates with increased responsiveness to EGFR tyrosine kinase 
inhibitors in patients with advanced NSCLC and that a substantial percentage of tumors with objective response to gefitinib or erlotinib harbours somatic mutations in the EGFR gene [42, 43, 65]. Moreover, clinical and demographic factors, including female sex, nonsmoking status, adenocarcinoma histotype, and Asian race have been identified as potentially predictive of the efficacy of EGFR tyrosine kinase inhibitors.

Currently, 4 randomized clinical trials have demonstrated the efficacy of gefitinib as a first-line treatment of NSCLC patients harbouring EGFR mutations: the IPASS and the First-SIGNAL studies, conducted in Asian patients selected for clinical factors; the WJTOG 3405 and the NEJ002 studies, conducted in patients selected for the presence of EGFR-activating mutations [57-60]. All these trials have demonstrated a statistically significant increase in progression-free survival with gefitinib compared to platinum-based chemotherapy in patients with EGFRmutated advanced NSCLC. Moreover, treatment with gefitinib was associated with evidence of high objective response rate, better quality of life and more favourable toxicity profile. On these bases, in July 2009 gefitinib received from EMEA the authorization for the treatment of locally advanced or metastatic NSCLC with activating mutations of EGFR, across all lines of therapy and, currently, it can be considered the standard first-line treatment of patients with advanced NSCLC harbouring EGFR mutations.

Similar results have been recently obtained with erlotinib in a phase 3 clinical trial conducted in China (the OPTIMAL trial), comparing erlotinib to gemcitabine plus carboplatin, in EGFR-mutation-positive tumors in terms of progressionfree survival [66]. The OPTIMAL study showed that erlotinib was significantly superior to chemotherapy in terms of progression-free survival (13.1 versus 4.6 months, HR 0.16, $95 \%$ CI: $0.10-0.26, P<.0001)$ and also in terms of objective response rate ( $83 \%$ versus $36 \%$ ).

On the contrary, a treatment strategy based on a tyrosine kinase inhibitor (erlotinib) as a first-line therapy, followed at progression by chemotherapy in unselected patients with advanced NSCLC, is inferior to standard treatment with a first-line platinum-based doublet, followed at progression by erlotinib and cannot be recommended in clinical practice [67].

Several questions need to be addressed, regarding the reproducibility of these results in Western patients with NSCLC and EGFR mutations, the proper tyrosine kinase selection (gefitinib versus erlotinib), the lack of a survival benefit with first-line gefitinib in all these studies, the most appropriate clinical use of TKIs in mutated patients (first versus second line), the efficacy of gefitinib as neoadjuvant therapy or in combination with radiotherapy in patients with locally advanced NSCLC and EGFR mutations, and overcoming resistance to tyrosine kinase inhibitors. A large randomized phase 3 trial (the EURTAC trial, ClinicalTrial.gov ID NCT00446225) testing erlotinib in Western patients harbouring EGFR mutation is addressing the first question. Conversely, there are no ongoing phase 3 trials that directly compare gefitinib with erlotinib: therefore, the choice of the tyrosine kinase inhibitor to use in clinical practice should be based on evidence coming from these randomized trials. Whether progression-free survival prolongation translates into survival gain is not yet clear: mature data from the IPASS trial showed no survival difference between first-line gefitinib and chemotherapy, probably due to treatment crossover of patients with tumor harbouring EGFR mutation [61].

The lack of a survival benefit with first-line gefitinib raises the question regarding its use as first- or secondline therapy, in patients selected by the presence of EGFR mutation. Data from Western and Asian patients suggest that there was no statistically significant difference in overall survival between patients receiving EGFR inhibitors as a first-line therapy or after failure of previous chemotherapy $[68,69]$. However, these analyses were not based on a prospective comparison between the two strategies (firstversus the second-line therapy with EGFR inhibitors). Moreover, it should be considered that, for patients who do not receive first-line tyrosine kinase inhibitors, there is the risk of never receiving an EGFR inhibitor at the time of disease progression, due to a rapid worsening of clinical conditions. Finally, the better quality of life and more favourable toxicity profile with first line gefitinib, in addition to the prolonged progression-free survival, compared to chemotherapy, strongly support the use of gefitinib as a firstline therapy in patients with activating EGFR mutations.

The final results of ongoing clinical trials should define the efficacy of gefitinib also as neoadjuvant therapy or in combination with radiotherapy in patients with locally advanced NSCLC and EGFR mutations, while the development of irreversible inhibitors of EGFR tyrosine kinases [70] may have the potential to overcome the resistance to tyrosine kinase inhibitors.

\section{References}

[1] J. Baselga and S. D. Averbuch, "ZD1839 ('Iressa') as an anticancer agent," Drugs, vol. 60, supplement 1, pp. 33-40, 2000.

[2] N. Normanno, C. Bianco, L. Strizzi et al., "The ErbB receptors and their ligands in cancer: an overview," Current Drug Targets, vol. 6, no. 3, pp. 243-257, 2005.

[3] M. A. Olayioye, R. M. Neve, H. A. Lane, and N. E. Hynes, "The ErbB signaling network: receptor heterodimerization in development and cancer," The EMBO Journal, vol. 19, no. 13, pp. 3159-3167, 2000.

[4] A. Wells, "EGF receptor," International Journal of Biochemistry and Cell Biology, vol. 31, no. 6, pp. 637-643, 1999.

[5] A. De Luca, A. Carotenuto, A. Rachiglio et al., "The role of the EGFR signaling in tumor microenvironment," Journal of Cellular Physiology, vol. 214, no. 3, pp. 559-567, 2008.

[6] A. E. Wakeling, S. P. Guy, J. R. Woodburn et al., "ZD1839 (Iressa): an orally active inhibitor of epidermal growth factor signaling with potential for cancer therapy," Cancer Research, vol. 62, no. 20, pp. 5749-5754, 2002.

[7] F. Ciardiello, R. Caputo, R. Bianco et al., "Antitumor effect and potentiation of cytotoxic drugs activity in human cancer cells by ZD-1839 (Iressa), an epidermal growth factor receptorselective tyrosine kinase inhibitor," Clinical Cancer Research, vol. 6 , no. 5, pp. 2053-2063, 2000. 
[8] F. M. Sirotnak, M. F. Zakowski, V. A. Miller, H. I. Scher, and M. G. Kris, "Efficacy of cytotoxic agents against human tumor xenografts is markedly enhanced by coadministration of ZD1839 (Iressa), an inhibitor of EGFR tyrosine kinase," Clinical Cancer Research, vol. 6, no. 12, pp. 4885-4892, 2000.

[9] H. Swaisland, A. Laight, L. Stafford et al., "Pharmacokinetics and tolerability of the orally active selective epidermal growth factor receptor tyrosine kinase inhibitor ZD1839 in healthy volunteers," Clinical Pharmacokinetics, vol. 40, no. 4, pp. 297306, 2001.

[10] M. Ranson, L. A. Hammond, D. Ferry et al., “ZD1839, a selective oral epidermal growth factor receptor-tyrosine kinase inhibitor, is well tolerated and active in patients with solid, malignant tumors: results of a phase I trial," Journal of Clinical Oncology, vol. 20, no. 9, pp. 2240-2250, 2002.

[11] J. Baselga, D. Rischin, M. Ranson et al., "Phase I safety, pharmacokinetic, and pharmacodynamic trial of ZD1839, a selective oral epidermal growth factor receptor tyrosine kinase inhibitor, in patients with five selected solid tumor types," Journal of Clinical Oncology, vol. 20, no. 21, pp. 4292-4302, 2002.

[12] R. S. Herbst, A. M. Maddox, M. L. Rothenberg et al., "Selective oral epidermal growth factor receptor tyrosine kinase inhibitor ZD1839 is generally well-tolerated and has activity in non-small-cell lung cancer and other solid tumors: results of a phase I trial," Journal of Clinical Oncology, vol. 20, no. 18, pp. 3815-3825, 2002.

[13] K. Nakagawa, T. Tamura, S. Negoro et al., "Phase I pharmacokinetic trial of the selective oral epidermal growth factor receptor tyrosine kinase inhibitor gefitinib ('Iressa', ZD1839) in Japanese patients with solid malignant tumors," Annals of Oncology, vol. 14, no. 6, pp. 922-930, 2003.

[14] G. Giaccone, J. L. González-Larriba, A. T. van Oosterom et al., "Combination therapy with gefitinib, an epidermal growth factor receptor tyrosine kinase inhibitor, gemcitabine and cisplatin in patients with advanced solid tumors," Annals of Oncology, vol. 15, no. 5, pp. 831-838, 2004.

[15] M. Fukuoka, S. Yano, G. Giaccone et al., "Multi-institutional randomized phase II trial of gefitinib for previously treated patients with advanced non-small-cell lung cancer (The IDEAL 1 Trial)," Journal of Clinical Oncology, vol. 21, no. 12, pp. 2237-2246, 2003.

[16] M. G. Kris, R. B. Natale, R. S. Herbst et al., "Efficacy of gefitinib, an inhibitor of the epidermal growth factor receptor tyrosine kinase, in symptomatic patients with non-small cell lung cancer: a randomized trial," Journal of the American Medical Association, vol. 290, no. 16, pp. 2149-2158, 2003.

[17] G. D’Addario, D. Rauch, R. Stupp et al., "Multicenter phase II trial of gefitinib first-line therapy followed by chemotherapy in advanced non-small-cell lung cancer (NSCLC): SAKK protocol 19/03," Annals of Oncology, vol. 19, no. 4, pp. 739745,2008 .

[18] M. Z. Wang, L. Y. Li, S. L. Wang et al., "Efficacy and safety of gefitinib as monotherapy for Chinese patients with advanced non-small cell lung cancer," Chinese Medical Journal, vol. 119, no. 1, pp. 63-68, 2006.

[19] W. C. Lin, C. H. Chiu, J. L. Liou et al., "Gefitinib as front-line treatment in Chinese patients with advanced non-small-cell lung cancer," Lung Cancer, vol. 54, no. 2, pp. 193-199, 2006.

[20] S. Niho, K. Kubota, K. Goto et al., "First-line single agent treatment with gefitinib in patients with advanced non-smallcell lung cancer: a phase II study," Journal of Clinical Oncology, vol. 24, no. 1, pp. 64-69, 2006.
[21] M. Reck, E. Buchholz, K. S. Romer et al., "Gefitinib monotherapy in chemotherapy-naive patients with inoperable stage III/IV non-small-cell lung cancer," Clinical Lung Cancer, vol. 7, no. 6, pp. 406-411, 2006.

[22] R. Suzuki, Y. Hasegawa, K. Baba et al., "A phase II study of single-agent gefitinib as first-line therapy in patients with stage IV non-small-cell lung cancer," British Journal of Cancer, vol. 94, no. 11, pp. 1599-1603, 2006.

[23] D. R. Spigel, J. D. Hainsworth, E. R. Burkett et al., "Singleagent gefitinib in patients with untreated advanced non-smallcell lung cancer and poor performance status: a minnie pearl cancer research network phase II trial," Clinical Lung Cancer, vol. 7, no. 2, pp. 127-132, 2005.

[24] G. Giaccone, R. S. Herbst, C. Manegold et al., "Gefitinib in combination with gemcitabine and cisplatin in advanced nonsmall-cell lung cancer: a phase III trial-INTACT 1," Journal of Clinical Oncology, vol. 22, no. 5, pp. 777-784, 2004.

[25] R. S. Herbst, G. Giaccone, J. H. Schiller et al., "Gefitinib in combination with paclitaxel and carboplatin in advanced nonsmall-cell lung cancer: a phase III trial-INTACT 2," Journal of Clinical Oncology, vol. 22, no. 5, pp. 785-794, 2004.

[26] U. Gatzemeier, A. Pluzanska, A. Szczesna et al., "Phase III study of erlotinib in combination with cisplatin and gemcitabine in advanced non-small-cell lung cancer: the Tarceva lung cancer investigation trial," Journal of Clinical Oncology, vol. 25, no. 12, pp. 1545-1552, 2007.

[27] R. S. Herbst, D. Prager, R. Hermann et al., "TRIBUTE: a phase III trial of erlotinib hydrochloride (OSI-774) combined with carboplatin and paclitaxel chemotherapy in advanced nonsmall-cell lung cancer," Journal of Clinical Oncology, vol. 23, no. 25, pp. 5892-5899, 2005.

[28] A. Morabito, M. C. Piccirillo, K. Monaco et al., "Methodological issues of clinical research with EGFR inhibitors," Current Cancer Therapy Reviews, vol. 3, no. 4, pp. 292-302, 2007.

[29] K. Takeda, T. Hida, T. Sato et al., "Randomized phase III trial of platinum-doublet chemotherapy followed by gefitinib compared with continued platinum-doublet chemotherapy in Japanese patients with advanced non-small-cell lung cancer: results of a west Japan thoracic oncology group trial (WJTOG0203)," Journal of Clinical Oncology, vol. 28, no. 5, pp. 753-760, 2010.

[30] N. Thatcher, A. Chang, P. Parikh et al., "Gefitinib plus best supportive care in previously treated patients with refractory advanced non-small-cell lung cancer: results from a randomised, placebo-controlled, multicentre study (Iressa Survival Evaluation in Lung Cancer)," The Lancet, vol. 366, no. 9496, pp. 1527-1537, 2005.

[31] F. R. Hirsch, M. Varella-Garcia, P. A. Bunn Jr. et al., "Molecular predictors of outcome with gefitinib in a phase III placebocontrolled study in advanced non-small-cell lung cancer," Journal of Clinical Oncology, vol. 24, no. 31, pp. 5034-5042, 2006.

[32] T. Cufer, E. Vrdoljak, R. Gaafar et al., "Phase II, open-label, randomized study (SIGN) of single-agent gefitinib (IRESSA) or docetaxel as second-line therapy in patients with advanced (stage IIIb or IV) non-small-cell lung cancer," Anti-Cancer Drugs, vol. 17, no. 4, pp. 401-409, 2006.

[33] E. S. Kim, V. Hirsh, T. Mok et al., "Gefitinib versus docetaxel in previously treated non-small-cell lung cancer (INTEREST): a randomised phase III trial," The Lancet, vol. 372, no. 9652, pp. 1809-1818, 2008. 
[34] J. Y. Douillard, F. A. Shepherd, V. Hirsh et al., "Molecular predictors of outcome with gefitinib and docetaxel in previously treated non-small-cell lung cancer: data from the randomized phase III INTEREST trial," Journal of Clinical Oncology, vol. 28, no. 5, pp. 744-752, 2010.

[35] R. Maruyama, Y. Nishiwaki, T. Tamura et al., "Phase III study, V-15-32, of gefitinib versus docetaxel in previously treated Japanese patients with non-small-cell lung cancer," Journal of Clinical Oncology, vol. 26, no. 26, pp. 4244-4252, 2008.

[36] D. H. Lee, K. Park, J. H. Kim et al., "Randomized phase III trial of gefitinib versus docetaxel in non-small cell lung cancer patients who have previously received platinum-based chemotherapy," Clinical Cancer Research, vol. 16, no. 4, pp. 1307-1314, 2010.

[37] F. A. Shepherd, J. Douillard, M. Fukuoka et al., "Comparison of gefitinib and docetaxel in patients with pretreated advanced non-small cell lung cancer (NSCLC): meta-analysis from four clinical trials," Journal of Clinical Oncology, vol. 27, no. 15, supplement, 2009, (abstract no. 8011).

[38] G. D. Goss, I. Lorimer, M. S. Tsao et al., "A phase III randomized, double-blind, placebo-controlled trial of the epidermal growth factor receptor inhibitor gefitinb in completely resected stage IB-IIIA non-small cell lung cancer (NSCLC): NCIC CTG BR.19," Journal of Clinical Oncology, vol. 28, no. 18, supplement, 2010, (abstract no. LBA7005).

[39] K. Kelly, K. Chansky, L. E. Gaspar et al., "Phase III trial of maintenance gefitinib or placebo after concurrent chemoradiotherapy and docetaxel consolidation in inoperable stage III non-small-cell lung cancer: SWOG S0023," Journal of Clinical Oncology, vol. 26, no. 15, pp. 2450-2456, 2008.

[40] L. Crinò, F. Cappuzzo, P. Zatloukal et al., "Gefitinib versus vinorelbine in chemotherapy-naive elderly patients with advanced non-small-cell lung cancer (INVITE): a randomized, phase II study," Journal of Clinical Oncology, vol. 26, no. 26, pp. 4253-4260, 2008.

[41] G. Goss, D. Ferry, R. Wierzbicki et al., "Randomized phase II study of gefitinib compared with placebo in chemotherapynaive patients with advanced non-small-cell lung cancer and poor performance status," Journal of Clinical Oncology, vol. 27, no. 13, pp. 2253-2260, 2009.

[42] T. J. Lynch, D. W. Bell, R. Sordella et al., "Activating mutations in the epidermal growth factor receptor underlying responsiveness of non-small-cell lung cancer to gefitinib," The New England Journal of Medicine, vol. 350, no. 21, pp. 2129$2139,2004$.

[43] J. G. Paez, P. A. Jänne, J. C. Lee et al., "EGFR mutations in lung, cancer: correlation with clinical response to gefitinib therapy," Science, vol. 304, no. 5676, pp. 1497-1500, 2004.

[44] H. Asahina, K. Yamazaki, I. Kinoshita et al., "A phase II trial of gefitinib as first-line therapy for advanced non-small cell lung cancer with epidermal growth factor receptor mutations," British Journal of Cancer, vol. 95, no. 8, pp. 998-1004, 2006.

[45] A. Inoue, T. Suzuki, T. Fukuhara et al., "Prospective phase II study of gefitinib for chemotherapy-naive patients with advanced non-small-cell lung cancer with epidermal growth factor receptor gene mutations," Journal of Clinical Oncology, vol. 24, no. 21, pp. 3340-3346, 2006.

[46] C. H. Yang, C. J. Yu, J. Y. Shih et al., "Specific EGFR mutations predict treatment outcome of stage IIIB/IV patients with chemotherapy-naive non-small-cell lung cancer receiving first-line gefitinib monotherapy," Journal of Clinical Oncology, vol. 26, no. 16, pp. 2745-2753, 2008.
[47] L. V. Sequist, R. G. Martins, D. Spigel et al., "First-line gefitinib in patients with advanced non-small-cell lung cancer harboring somatic EGFR mutations," Journal of Clinical Oncology, vol. 26, no. 15, pp. 2442-2449, 2008.

[48] A. Sutani, Y. Nagai, K. Udagawa et al., "Gefitinib for nonsmall-cell lung cancer patients with epidermal growth factor receptor gene mutations screened by peptide nucleic acidlocked nucleic acid PCR clamp," British Journal of Cancer, vol. 95, no. 11, pp. 1483-1489, 2006.

[49] K. Yoshida, Y. Yatabe, J. Y. Park et al., "Prospective validation for prediction of gefitinib sensitivity by epidermal growth factor receptor gene mutation in patients with non-small cell lung cancer," Journal of Thoracic Oncology, vol. 2, no. 1, pp. 22-28, 2007.

[50] N. Sunaga, Y. Tomizawa, N. Yanagitani et al., "Phase II prospective study of the efficacy of gefitinib for the treatment of stage III/IV non-small cell lung cancer with EGFR mutations, irrespective of previous chemotherapy," Lung Cancer, vol. 56, no. 3, pp. 383-389, 2007.

[51] K. Tamura, I. Okamoto, T. Kash II et al., "Multicentre prospective phase II trial of gefitinib for advanced nonsmall cell lung cancer with epidermal growth factor receptor mutations: results of the West Japan Thoracic Oncology Group trial (WJTOG0403)," British Journal of Cancer, vol. 98, no. 5, pp. 907-914, 2008.

[52] K. Sugio, H. Uramoto, T. Onitsuka et al., "Prospective phase II study of gefitinib in non-small cell lung cancer with epidermal growth factor receptor gene mutations," Lung Cancer, vol. 64, no. 3, pp. 314-318, 2009.

[53] A. Inoue, K. Kobayashi, K. Usui et al., "First-line gefitinib for patients with advanced non-small-cell lung cancer harboring epidermal growth factor receptor mutations without indication for chemotherapy," Journal of Clinical Oncology, vol. 27, no. 9, pp. 1394-1400, 2009.

[54] F. Cappuzzo, C. Ligorio, P. A. Jänne et al., "Prospective study of gefitinib in epidermal growth factor receptor fluorescence in situ hybridization-positive/phospho-akt-positive or never smoker patients with advanced non-small-cell lung cancer: the ONCOBELL trial," Journal of Clinical Oncology, vol. 25, no. 16, pp. 2248-2255, 2007.

[55] H. L. West, W. A. Franklin, J. McCoy et al., "Gefitinib therapy in advanced bronchioloalveolar carcinoma: Southwest Oncology Group study S0126," Journal of Clinical Oncology, vol. 24, no. 12, pp. 1807-1813, 2006.

[56] D. H. Lee, J. Y. Han, H. G. Lee et al., "Gefitinib as a first-line therapy of advanced or metastatic adenocarcinoma of the lung in never-smokers," Clinical Cancer Research, vol. 11, no. 8, pp. 3032-3037, 2005.

[57] T. S. Mok, Y. L. Wu, S. Thongprasert et al., "Gefitinib or carboplatin-paclitaxel in pulmonary adenocarcinoma," The New England Journal of Medicine, vol. 361, no. 10, pp. 947$957,2009$.

[58] J. S. Lee, K. Park, S. W. Kim et al., "A randomized phase III study of gefitinib (IRESSA) versus standard chemotherapy (gemcitabine plus cisplatin) as a first-line treatment for neversmokers with advanced or metastatic adenocarcinoma of the lung," in Proceedings of the World Conference on Lung Cancer, 2009, (abstract no. PRS.4).

[59] T. Mitsudomi, S. Morita, Y. Yatabe et al., "Gefitinib versus cisplatin plus docetaxel in patients with non-small-cell lung cancer harbouring mutations of the epidermal growth factor receptor (WJTOG3405): an open label, randomised phase 3 trial," The Lancet Oncology, vol. 11, no. 2, pp. 121-128, 2010. 
[60] M. Maemondo, A. Inoue, K. Kobayashi et al., "Gefitinib or chemotherapy for non-small-cell lung cancer with mutated EGFR," The New England Journal of Medicine, vol. 362, no. 25, pp. 2380-2388, 2010.

[61] C. H. Yang, M. Fukuoka, T. S. Mok et al., "Final overall survival results from a phase III, randomised, open-label, firstline study of gefitinib vs. carboplatin/paclitaxel in clinically selected patients with advanced non-small cell lung cancer in Asia (IPASS)," in Proceedings of the European Society of Medical Oncology Meeting, 2010, (abstract no. LBA2).

[62] M. Di Maio, C. Gallo, E. De Maio et al., "Methodological aspects of lung cancer clinical trials in the era of targeted agents," Lung Cancer, vol. 67, no. 2, pp. 127-135, 2010.

[63] A. Morabito, M. Di Maio, E. De Maio, N. Normanno, and F. Perrone, "Methodology of clinical trials with new moleculartargeted agents: where do we stand?" Annals of Oncology, vol. 17, supplement 7, pp. vii128-vii131, 2006.

[64] R. A. Betensky, D. N. Louis, and J. G. Cairncross, "Influence of unrecognized molecular heterogeneity on randomized clinical trials," Journal of Clinical Oncology, vol. 20, no. 10, pp. 24952499, 2002.

[65] T. Mitsudomi, T. Kosaka, H. Endoh et al., "Mutations of the epidermal growth factor receptor gene predict prolonged survival after gefitinib treatment in patients with non-smallcell lung cancer with postoperative recurrence," Journal of Clinical Oncology, vol. 23, no. 11, pp. 2513-2520, 2005.

[66] C. Zhou, Y. I. Wung, G. Chen et al., "Efficacy results from the randomised phase III OPTIMAL (CTONG 0802) study comparing first-line erlotinib versus carboplatin plus gemcitabine, in chinese advanced non-small-cell lung cancer patients with EGFR activating mutations," in Proceedings of the European Society of Medical Oncology Meeting, 2010, (abstract no. LBA13).

[67] C. Gridelli, F. Ciardiello, R. Feld et al., "International multicenter randomized phase III study of first-line erlotinib (E) followed by second-line cisplatin plus gemcitabine (CG) versus first-line CG followed by second-line $\mathrm{E}$ in advanced non-small cell lung cancer (aNSCLC): the TORCH trial," Journal of Clinical Oncology, vol. 28, no. 15, supplement, 2010, (abstract no. 7508).

[68] R. Rosell, T. Moran, C. Queralt et al., "Screening for epidermal growth factor receptor mutations in lung cancer," The New England Journal of Medicine, vol. 361, no. 10, pp. 958-967, 2009.

[69] S. Morita, I. Okamoto, K. Kobayashi et al., "Combined survival analysis of prospective clinical trials of gefitinib for nonsmall cell lung cancer with EGFR mutations," Clinical Cancer Research, vol. 15, no. 13, pp. 4493-4498, 2009.

[70] C. P. Belani, "The role of irreversible EGFR inhibitors in the treatment of non-small cell lung cancer: overcoming resistance to reversible EGFR inhibitors," Cancer Investigation, vol. 28, no. 4, pp. 413-423, 2010. 


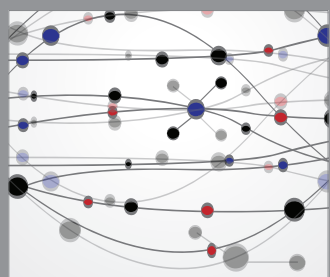

The Scientific World Journal
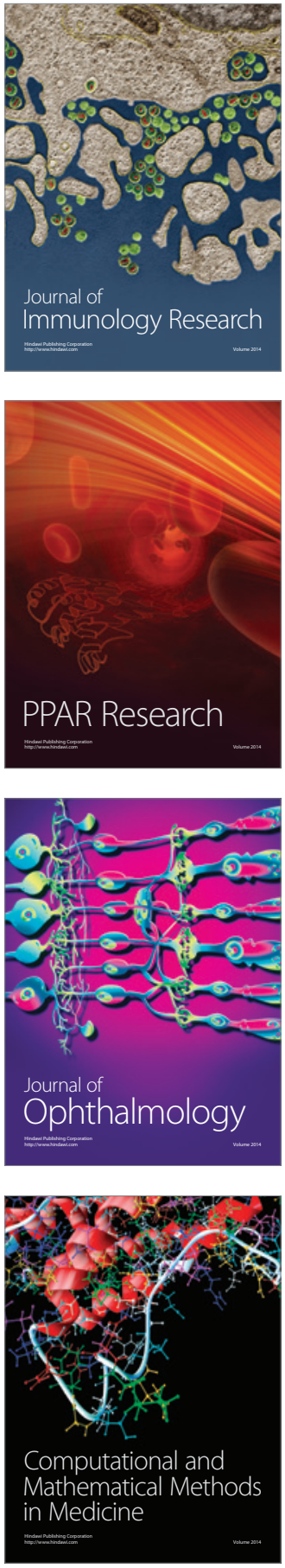

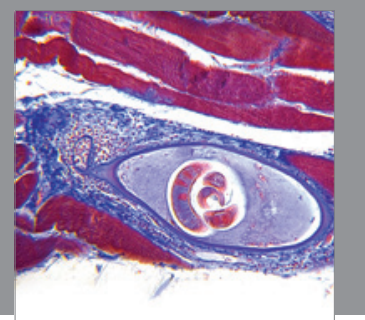

Gastroenterology

Research and Practice
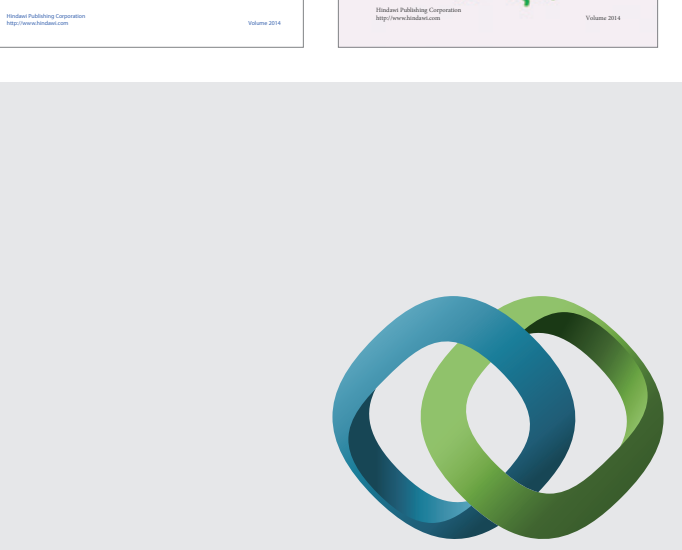

\section{Hindawi}

Submit your manuscripts at

http://www.hindawi.com
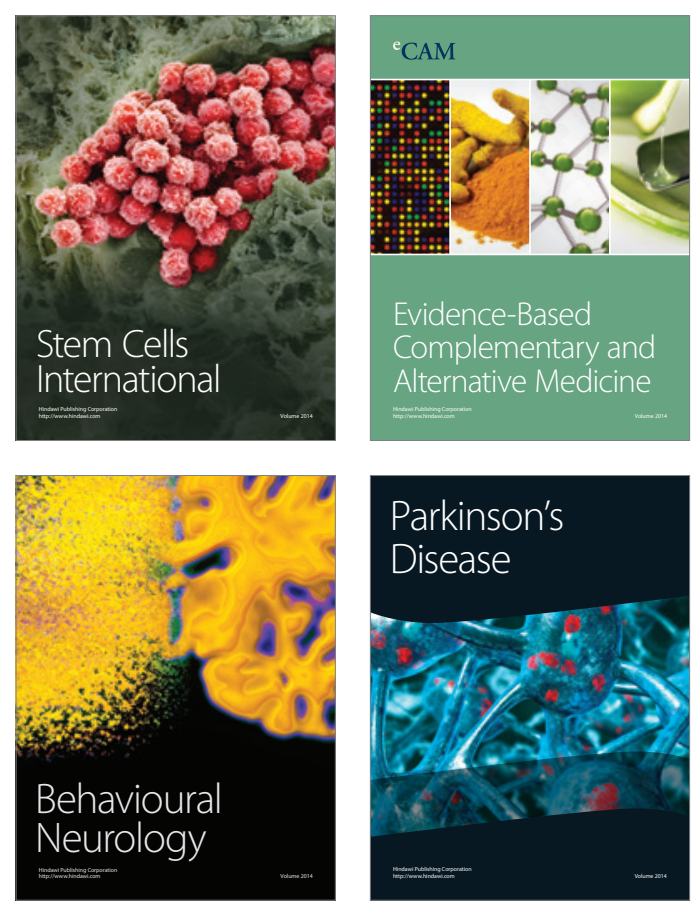

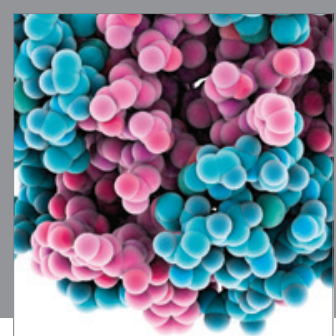

Journal of
Diabetes Research

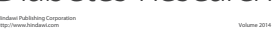

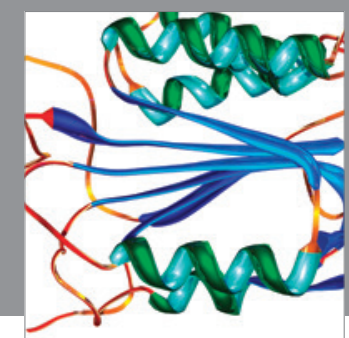

Disease Markers
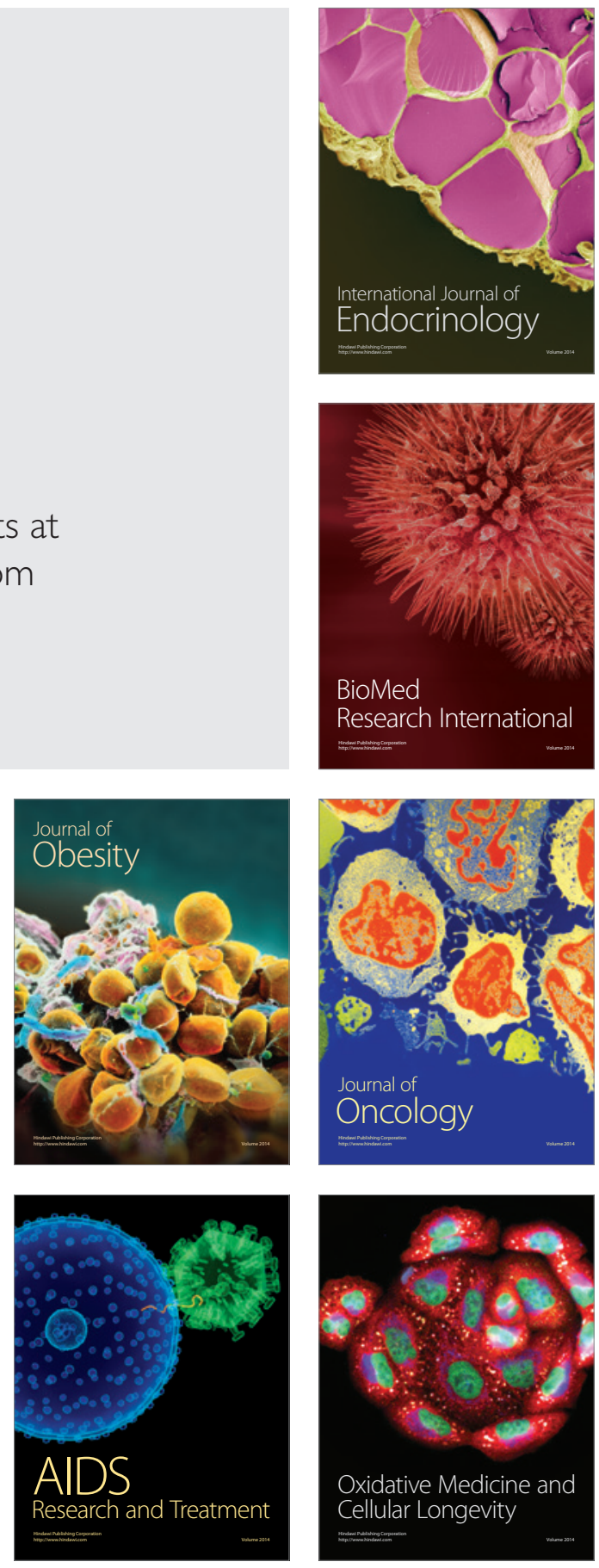